\title{
Modelling Rice-Weed Competition in Direct-Seeded Rice Cultivation
}

\author{
Md Abdullah Al Mamun
}

Received: 2 November 2013/Accepted: 4 June 2014/Published online: 9 November 2014

(C) The Author(s) 2014. This article is published with open access at Springerlink.com

\begin{abstract}
Two field experiments were conducted to investigate rice-weed competition during direct-seeded rice cultivation. A rectangular hyperbolic equation was used to predict rice yield as a function of weed densities. Economic thresholds (ET) of multi-species weeds were estimated considering the cost of weed control and price of rice yield. The dry matter production and intraspecific competition of weeds were 1.13-3.63 g plant ${ }^{-1}$ and $0.0375-0.0383$, respectively. The competition effect of weeds on rice was significant and the competitivity value ranged from 0.0170 to 0.0126 . Therefore, the number of panicles $\mathrm{m}^{-2}$, grains panicle ${ }^{-1}$ and 1,000-grain weight were significantly reduced by the competition of weed species. Considering the weed competitivity, weed control costs and price of grain, the ET values of weeds were 4.72-9.17 plants $\mathrm{m}^{-2}$. These findings will be useful for weed management in direct-seeded rice cultivation.
\end{abstract}

Keywords Direct-seeded rice $\cdot$ Economic threshold $\cdot$ Multi species weeds $\cdot$ Rice-weed competition

\section{Introduction}

Rice (Oryza sativa L.) is an important staple food in Asia. Growers in many Asian countries (e.g. the Philippines, Bangladesh and India) are shifting their production system from traditional puddle-transplanting rice to direct-seeded rice [3]. Direct-seeded rice (DSR) has several advantages such as being labor intensive and consuming less water [2], but weeds are the main biological constraint in this system. Because weed and rice seedlings emerge simultaneously and there is no standing water to suppress weeds at the time of crop emergence [1], weed control is an essential and important component of rice production because uncontrolled weeds can lead to rice yield losses as high as $80 \%$ [16]. Accurate prediction of weed-crop interactions is necessary to manage weeds successfully [18]. An empirical model of the impact of weed interference on crop yield

M. Abdullah Al Mamun ( $₫)$

Department of Agronomy, Bangabandhu Sheikh Mujibur

Rahman Agricultural University, Gazipur, Bangladesh

e-mail: aamamunbrri@yahoo.com provides useful information for integrated weed management decisions [20]. Different mathematical weed-crop interference models have been developed to quantify competitive relationships and predict yield loss [4], [9]. However, the weed density-based rectangular hyperbola model [4] has been most widely used to predict crop yield losses and has been successfully used in wheat [8], soybean [6] and maize [10]. An ecophysiological model was introduced by Lindquist and Kropff (1996) [10] for irrigated rice-Echinochloa competition. A response-surface model based on the rectangular hyperbola was proposed by $\mathrm{Ni}$ et al. [14] to analyse competition between rice and E. crus-galli. Most of the studies evaluate the interference between a single weed species and the crop, whereas in the field situation there are several weed species that could reduce crop yield. As a result, most of these studies have not had an important role in weed control decision-making [15]. Therefore, two field experiments were conducted to investigate competition relationships between weeds and rice, to predict crop yield using the rectangular hyperbola model and to determine the economic threshold levels of multi-species weeds in direct-seeded rice production systems. 


\section{Materials and Methods}

\section{Field Location}

Two field experiments were conducted at the research field of the Bangladesh Rice Research Institute, Gazipur district $\left(90^{\circ} 33^{\prime} \mathrm{E}\right.$ longitude and $23^{\circ} 77^{\prime} \mathrm{N}$ latitude), during the main rice-growing season (June to November) in 2009 and 2010. The region has a sub-tropical humid climate, with two distinct seasons: a dry season from November to May and a rainy season from June to October. The same field was used both years. The experimental field has shallow red-brown terrace soil. The soil is loamy with $\mathrm{pH} 6.2$ and $1.4,47,35$ and $18 \%$ organic matter, sand, silt and clay, respectively. The field is characterised by different native weed species.

\section{Execution of Field Experiments}

RRRI dhan49 (a semi-dwarf rice variety with growth duration of around 135 days and a popular variety in Bangladesh) was sown on 5 and 7 July in 2009 and 2010, respectively. Land was ploughed 1 month before sowing and then harrowed. Plot sizes were $1 \times 1 \mathrm{~m}$. A randomised complete block design with three replicates was used. Between plots, a 40-cm-high, 30-cm-wide ridge was constructed. Before sowing, the plot was kept weed-free by hand weeding. Basal application of fertiliser at a rate of $90 \mathrm{~kg} \mathrm{~N} \mathrm{ha}^{-1}$ as urea, phosphorus of $20 \mathrm{~kg} \mathrm{P} \mathrm{ha}^{-1}$ as triple super phosphate and $35 \mathrm{~kg} \mathrm{~K} \mathrm{ha}^{-1}$ as muriate of potash were broadcast uniformly and incorporated into the soil of all plots. Except urea, all other fertilisers were applied before rice sowing, and urea was top dressed in three installments at 15, 30 and 45 DAS. Pesticides and herbicides were not applied during crop growth. Rice seeds were sown by hand broadcasting at a rate of $40 \mathrm{~kg} \mathrm{ha}^{-1}$. The rice seedlings and weeds grew at the same time. Treatments consisted of $0,5,10,20,40,80$ and 160 weeds $\mathrm{m}^{-2}$. Weeds of different species were maintained from 10 to 50 days after sowing (DAS) at 10-day intervals. Newly emerged weeds were uprooted to maintain the desired weed number per $\mathrm{m}^{-2}$. The data on weed dry matter, panicles per $\mathrm{m}^{-2}$, grains per panicle ${ }^{-1}, 1,000$-grain weight and grain yield were recorded. Grain yield was adjusted at $14 \%$ moisture content.

\section{Prediction Model and Statistical Analysis}

There was a hyperbolic relationship between weed biomass and density [21]. The relationship between weed biomass (W) and density (X) was determined using the following equation:
$\mathrm{W}=\mathrm{C} \mathrm{X} /(1+\alpha \mathrm{X})$

where, $\mathrm{C}$ is the dry weight of weeds $\left(\mathrm{g}_{\text {plant }}{ }^{-1}\right.$ ) without competition and $\alpha$ is with weed competition.

The rectangular hyperbola model [4] as a function of weed density was used to predict rice grain yield by fitting rice biomass and grain yields to Eq. 2 .

$\mathrm{Y}=\mathrm{Y}_{\mathrm{o}} /(1+\beta \mathrm{X})$

where $\mathrm{Y}_{\mathrm{o}}$ is weed-free rice yield $\left(\mathrm{tha}^{-1}\right), \beta$ is a measure of weed competitivity (a weed density of $1 / \beta$ reduces the rice yield by $50 \%$ ) and $\mathrm{X}$ is weed density.

Economic thresholds (ETs) of weeds were estimated by equating [5] the weed control cost (herbicide and application cost) with the price of rice gain yield.

$\mathrm{ET}=\left(\mathrm{C}_{\mathrm{h}}+\mathrm{C}_{\mathrm{a}}\right) /\left(\mathrm{Y}_{\mathrm{o}} \mathrm{P} \mathrm{L} \mathrm{H}\right)$,

where $\mathrm{C}_{\mathrm{h}}$ is herbicide cost (US $\$ \mathrm{ha}^{-1}$ ), $\mathrm{C}_{\mathrm{a}}$ is application cost (US $\left.\$ \mathrm{ha}^{-1}\right), \mathrm{Y}_{\mathrm{o}}$ is weed-free rice yield $\left(\mathrm{tha}^{-1}\right), \mathrm{P}$ is the value per unit of crop (US $\$ \mathrm{t}^{-1}$ ), $\mathrm{L}$ is proportional loss per unit weed density, and $\mathrm{H}$ is herbicide efficacy. All statistical analyses were conducted using MSTAT-C.

\section{Results}

Weed Vegetation

Twelve weed species inhabited the rice field. The infesting weed species belonged to 6 families and 11 genera (data not shown). This weed flora was ecologically categorised into four broadleaf species, four sedges and four grasses. The number of weed species was higher in 2010 (ten species) than in 2009 (nine species). The sedges were Scirpus maritimus L., Cyperus difformis L., Fimbristylis miliacea L. and Cyperus iria L. Echinochloa crus-galli L., Leersia hexandra Sw., Cynodon dactylon L. Pers. and Leptochloa chinensis L. Ness. were grasses and Monochoria vaginalis Burm. f., Marsilea minuta L. Ludwigia octovalvis Jacq. and Sphenoclea zeylanica Gaertn were broad leaf weeds.

\section{Rice-Weed Competition}

Weed dry matter of different densities was measured at 50 days after sowing (DAS) to characterise and compare the competition effects of weeds on rice biomass and the number of tillers. The growth and dry weight of weeds were different from the first to second year. Weeds produced more of less double dry matter in 2009 compared to 2010. Weed dry weights increased hyperbolically with increasing weed density. The intraspecific competition was significant (Fig. 1). Weed dry weight was fitted to Eq. 1 to 


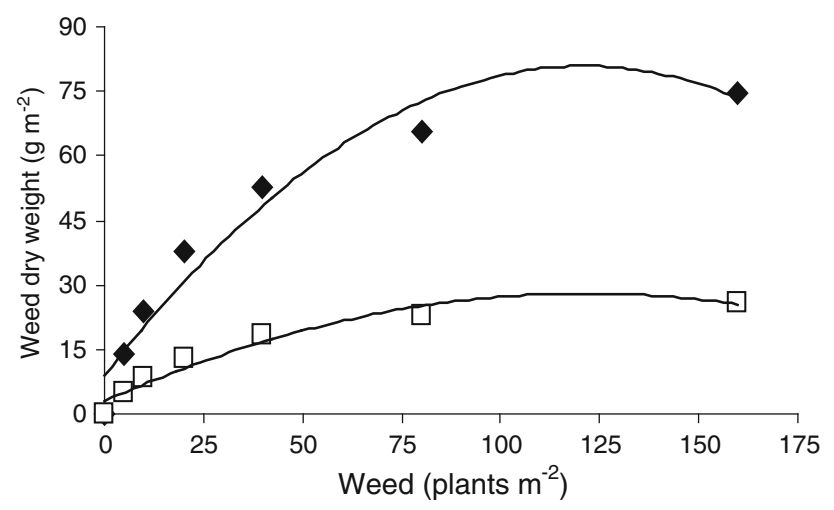

Fig. 1 Weed dry matter production at 50 DAS in 2009 (filled diamond) and 2010 (white square). Weed dry matter production was fitted with Eq. 1 to determine $\mathrm{C}$ and $a$

estimate individual weed dry weight (C) and intraspecific competitivity $(\alpha)$. The individual dry weight of weeds was 3.63 and $1.13 \mathrm{~g} \mathrm{plant}^{-1}$ in 2009 and 2010, respectively. The intraspecific competition was 0.0383 and 0.0375 in 2009 and 2010, respectively.

The number of rice tillers was counted at 15-day intervals starting from 30 DAS up to harvesting. The weed density significantly reduced the number of rice tillers at different days after sowing (Fig. 2). A linear increase of tillers was obtained up to 60 DAS and maximum tiller was counted at 60 to 75 DAS. Tiller production was sharply decreased after 75 DAS and then gradually decreased. The highest number of tillers was obtained from the weed-free plots and the minimum from the 160 -weed- $\mathrm{m}^{-2}$ plot. A similar trend was found in both years.

Rice dry matter production was slightly more in 2010 than 2009. Competition effects were measured and showed that weeds caused a significant reduction in the rice dry weight (Fig. 3). The weed competitivity $(\beta)$ was estimated by fitting to Eq. 2 (Table 1).

Correlation and linear regression analyses were done to determine the effects of weed interference on rice yield

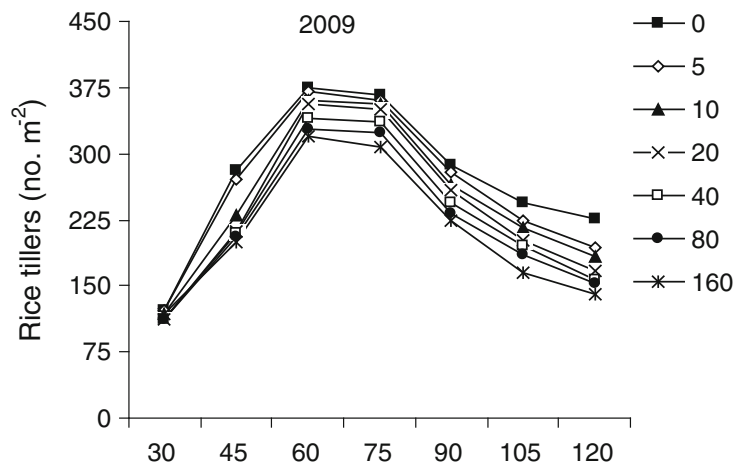

Days after sowing components in both years. Components such as the rice dry weight, number of panicles per $\mathrm{m}^{-2}$, grain per panicle ${ }^{-1}$, 1,000 -grain weight and \% fertility were negatively affected by weed density (Fig. 4). In 2009, the number of grains per panicle ${ }^{-1}$ followed by $\%$ fertility was strongly negatively affected by weed density (Fig. 4). A more or less similar negative effect was obtained for rice dry matter and panicles per $\mathrm{m}^{-2}$. The minimum effect was obtained for 1,000-grain weight in 2009. In the second year, all the parameters except \% fertility were strongly negatively affected. Again, there was a strong positive correlation between rice yield and all the parameters measured in both years.

Regression analyses showed that all the components contributing to rice yield were negatively affected by weed densities (Fig. 5). The reduction rate of panicles per $\mathrm{m}^{-2}$ and grains per panicle ${ }^{-1}$ was about 1.4 and 1.0 times more rapid in 2009 compared to 2010. On the other hand, 1,000grain yield and \% fertility decreased 1.4 and 1.6 times more rapidly in 2010 than in 2009 , respectively.

\section{Predicted Rice Yield}

Weed-free rice yield $\left(\mathrm{Y}_{\mathrm{o}}\right)$ and competitivity $(\beta)$ were estimated in both years by fitting the rectangular hyperbola (Eq. 2) to rice yield. The estimated weed-free rice yield was $4.63 \mathrm{t} \mathrm{ha}^{-1}$ in 2009, while it was $4.75 \mathrm{t} \mathrm{ha}^{-1}$ in 2010 (Table 2). The competitivities were 0.01695 and 0.01255 in 2009 and 2010, respectively. Simulating rice yield as a function of weed density using Eq. 2 (Fig. 6) showed that the competition between rice and weeds was described by a rectangular hyperbolic model in both years.

\section{Prediction of Economic Thresholds}

Using Eq. 3, economic thresholds of weeds were calculated. Considered parameters were herbicide prices 4.23-11.54 US $\$ \mathrm{ha}^{-1}$, application cost 17.95 US $\$ \mathrm{ha}^{-1}$,

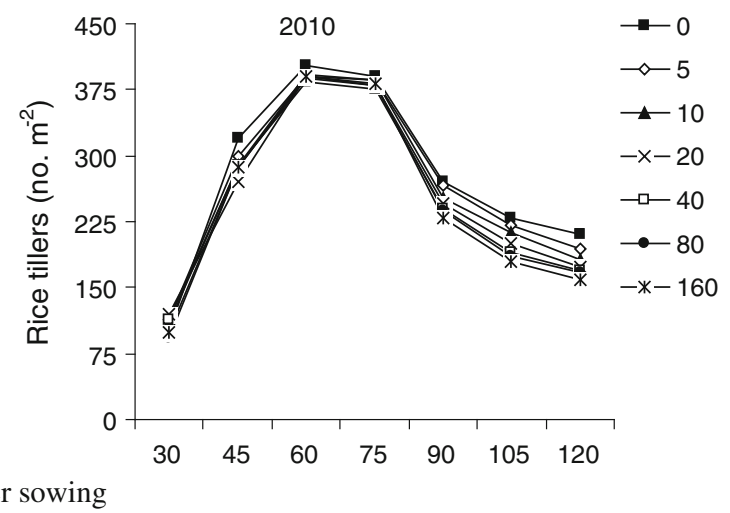

Fig. 2 Rice tiller production as affected by different weed densities 


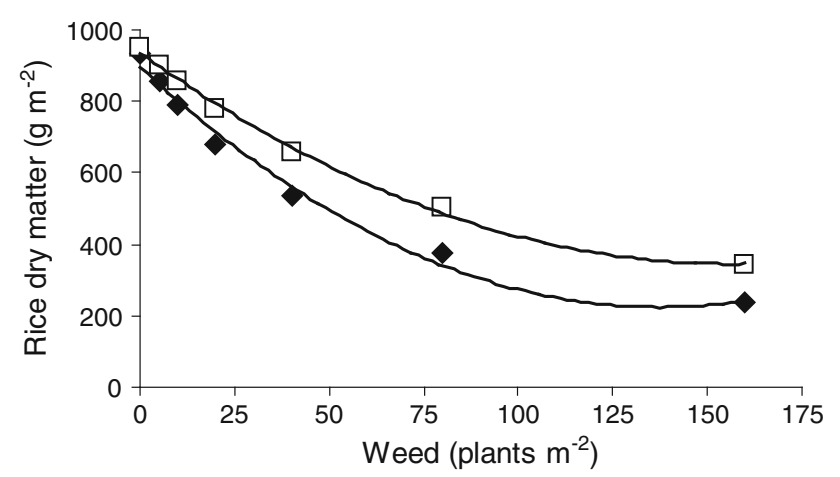

Fig. 3 Effect of weed densities on rice dry matter production at harvest [2009 (filled diamond) and 2010 (white square)]

Table 1 Weed-free rice dry matter production $\left(\mathrm{Y}_{0}\right)$ and competitivity $(\beta)$ at harvest as a result of competition between rice and weeds

\begin{tabular}{llll}
\hline Year & $\mathrm{Y}_{0}$ & $\beta$ & $\mathrm{R}^{2}$ \\
\hline 2009 & 934.08 & 0.01853 & 0.89 \\
2010 & 952.64 & 0.01115 & 0.84 \\
\hline
\end{tabular}

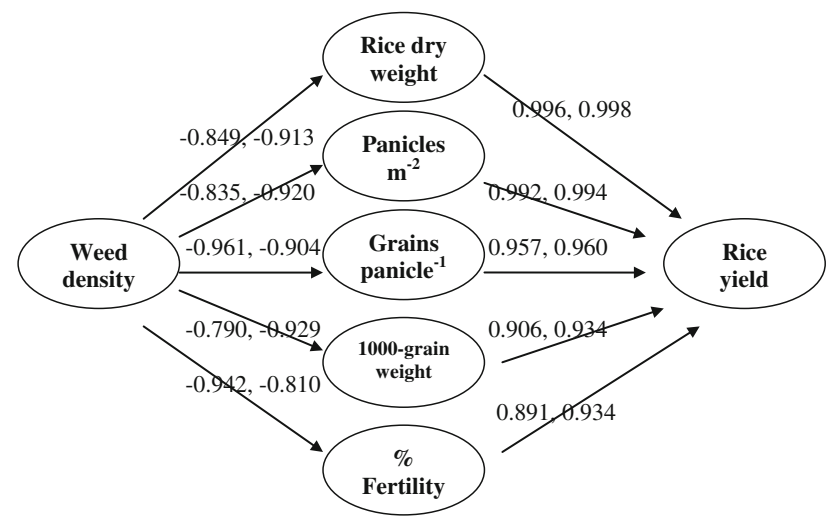

Fig. 4 Relationship of rice yield components with weed densities and rice yield in 2009 (correlation coefficient in left) and 2010 (correlation coefficient in right)

weed-free rice yield 4.63 (2009) to $4.75 \mathrm{t} \mathrm{ha}^{-1}$ (2010) and price of rice 192.31 US $\$ \mathrm{ha}^{-1}$ (Table 3). The estimated economic thresholds (ETs) of multi-species weeds were 6.75 and 4.72 plants $\mathrm{m}^{-2}$ in 2009 , but 9.17 and 6.90 plants $\mathrm{m}^{-2}$ in 2010 for pre- and post-emergence herbicide, respectively (Table 3). The overall ET of weeds in 2009 was smaller than in 2010 because of its greater competitivity. Again, the ET of weeds using post-emergence herbicide was smaller than that of pre-emergence herbicide because of cheaper herbicide costs. This could be recommended at plant densities of weeds of 4.72 to 9.17 plants $\mathrm{m}^{-2}$.

\section{Discussion}

In recent times, direct-seeded rice cultivation has been emerging in rice production technology in Asia. This technique improves labor and water productivity, making irrigated rice production more sustainable and profitable than transplanted rice systems [11]. However, weeds are the major problem in direct-seeded rice systems, and efforts are being made to develop and improve effective and sustainable weed management strategies in these systems [2]. This study was conducted to measure the competitivity between weeds and rice, to predict crop yields using the rectangular hyperbola model and to determine the economic threshold levels of weeds in direct-seeded rice cultivation.

Direct-seeded rice was broadcasted onto saturated or unflooded soil. Weeds emerged before or at thesame time as the rice, and weeds grew faster than rice at early growth stages. A saturated soil condition was favorable for weed emergence. Weeds of numerous genera infested the experimental sites, but sedges, grasses and broadleaf were present in equal numbers. Among the infesting weeds, Echinochloa crusgalli L. and Scirpus maritimus L. were the most important weeds. Tanaka (1976) [19] reported that sedges and grasses attained more dry matter in saturated soil. Again, Echinochloa crusgalli was found to be the dominant weed species in transplanted rice [12]. The dry matter of weeds increased with increasing weed density. The rate of increment was rapid at lower weed density, but increased at a decreasing rate after a certain density. At lower weed density, the intraspecific competition was low, and as a result individual weeds attained higher dry matter. However, competition among weeds increased with increasing density, resulting in the accumulation of less dry matter by individual weeds. Byeong Chul Moon et al. (2010) [13] observed no intraspecific competition among the weeds 30 days after transplanting.

Counting the number of tillers per unit area is a useful technique for measuring rice-weed competition. Increasing weed density reduced the number of tillers $\mathrm{m}^{-2}$ of rice plants in both years. Sultana [17] observed about $52 \%$ reduction in tillers due to competition from weeds. Fazlul et al. [7] also observed the significantly highest number of total tillers produced in weed-free treatments. Dry matter production by rice decreased with increasing weed density. At lower weed density the competition between rice and weeds was low and rice accumulated more dry matter. Weeds compete with rice for nutrients, water, sunlight and space. Thus, competition became more severe when the plant population was higher per unit area. Different rice 

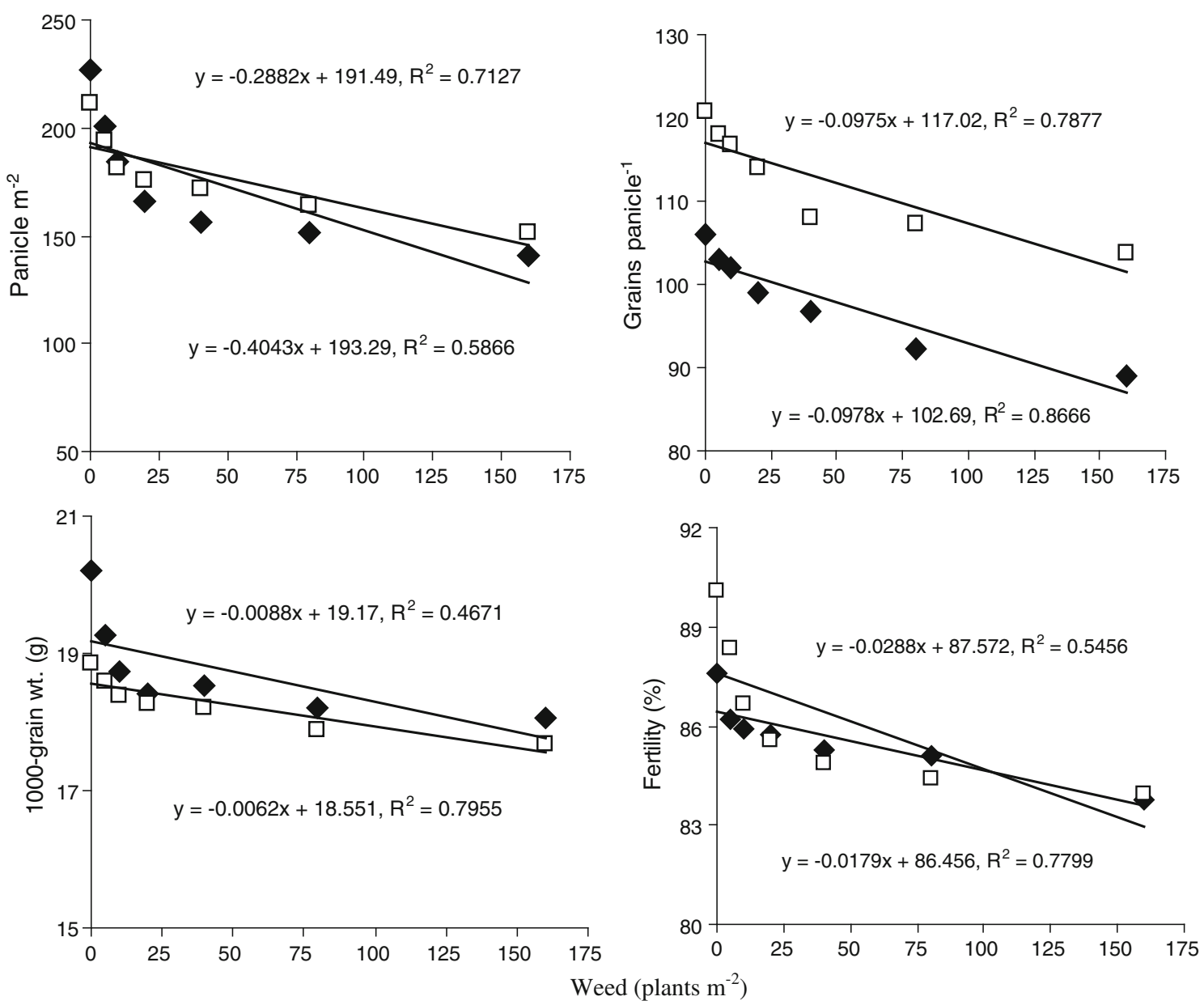

Fig. 5 Relationship between weed densities and rice yield components in 2009 (filled diamond) and 2010 (white square)

Table 2 Parameter estimates for the prediction of rice grain yield at harvest as a result of competition between rice and weeds

\begin{tabular}{llll}
\hline Year & $\mathrm{Y}_{0}$ & $\beta$ & $\mathrm{R}^{2}$ \\
\hline 2009 & 4.63 & 0.01695 & 0.91 \\
2010 & 4.75 & 0.01255 & 0.86 \\
\hline
\end{tabular}

$\mathrm{Y}_{0}$, weed-free rice yield $\left(\mathrm{t} \mathrm{ha}^{-1}\right) ; \beta$, measurement of weed competitivity

yield components were negatively affected by weed density. Competition of weed species with rice significantly affects rice dry matter production, the number of tillers, panicles per $\mathrm{m}^{-2}$, grains per panicle ${ }^{-1}, 1,000$-grain weight and $\%$ fertility. In 2009, weed density exerted a strong negative effect on grains per panicle ${ }^{-1}$ and $\%$ fertility but had less effect on 1,000-grain weight. Production of rice dry matter and panicles per $\mathrm{m}^{-2}$ was similarly affected by weed density. However, weed density strongly affected all the yield parameters in 2010. A strong positive relationship was obtained between yield components and yield in both years. Byeong Chul Moon et al. [13] reported that there was a strong negative relationship between the density of
Echinochloa crusgalli and different yield components of rice. They also found a strong positive relation between yield components and yield.

The predicted and observed yield of rice was more or less similar at low weed density, but with increased weed density the predicted yield decreased. A similar trend was obtained for both years. Determination of the ET of weed density consisting of the number of weeds in direct-seeded rice is one possible way to improve farming methods. The ET varied with rice-weed competition, rice yield and price, and herbicide cost.

The ET of E. crus-galli was 2.93 plants $\mathrm{m}^{-2}$ where the

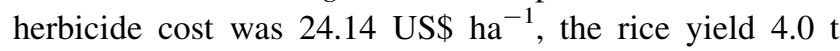

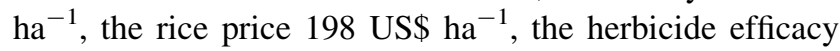
0.9 and yield loss $0.016 \%$ plant $^{-1}$ [10]. However, this study suggests ET values ranging from 4.72 to 9.17 plants $\mathrm{m}^{-2}$ depending on herbicide cost and yield. However, the ET values were less in developed countries such as Korea and Japan where herbicide costs are much higher than in developing countries such as Bangladesh. Again, the high rice price in Korea decreased the ET value significantly. 


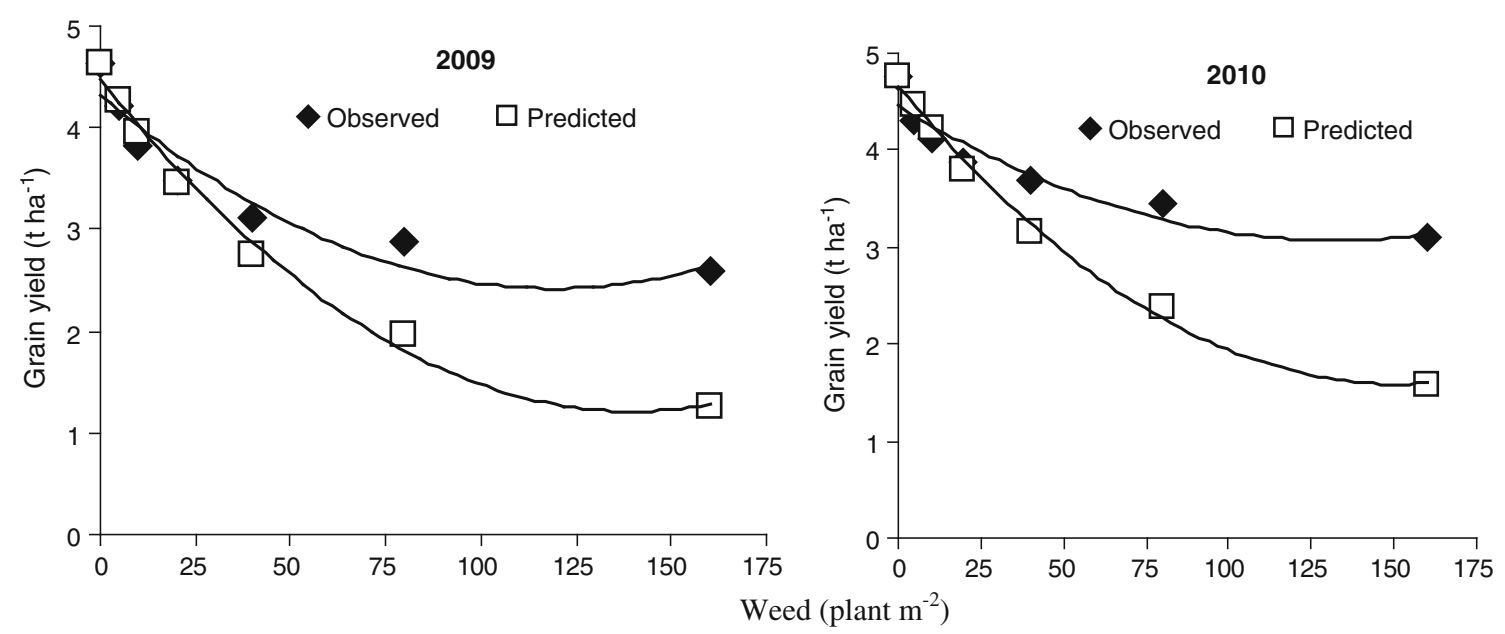

Fig. 6 Observed (filled diamond) and predicted (white square) rice grain yields as a function of weed density. The predicted rice grain yield was calculated using Eq. 2 and the parameter estimates in Table 2

Table 3 Parameter estimates and economic threshold (ET) of weeds in direct-seeded rice cultivation

\begin{tabular}{|c|c|c|c|c|c|c|c|c|c|}
\hline \multirow[t]{3}{*}{ Year } & \multicolumn{9}{|c|}{ Parameter estimates and economic threshold (ET) } \\
\hline & \multicolumn{2}{|c|}{$\mathrm{C}_{\mathrm{h}}\left(\$ \mathrm{ha}^{-1}\right)$} & \multirow[t]{2}{*}{$\mathrm{C}_{\mathrm{a}}\left(\$ \mathrm{ha}^{-1}\right)$} & \multirow[t]{2}{*}{$Y_{o}\left(\mathrm{t} \mathrm{ha}^{-1}\right)$} & \multirow[t]{2}{*}{$\mathrm{P}\left(\$ \mathrm{t}^{-1}\right)$} & \multirow[t]{2}{*}{$\mathrm{L}$} & \multirow[t]{2}{*}{$\mathrm{H}$} & \multicolumn{2}{|c|}{ ET $\left(\right.$ no. $\left.\mathrm{m}^{-2}\right)$} \\
\hline & A & $\mathrm{B}$ & & & & & & A & B \\
\hline 2009 & 11.54 & 4.23 & 17.95 & 4.63 & 192.31 & 0.0066 & 0.8 & 6.75 & 4.72 \\
\hline 2010 & 11.54 & 4.23 & 17.95 & 4.75 & 192.31 & 0.0044 & 0.8 & 9.17 & 6.90 \\
\hline
\end{tabular}

$C_{h}$ herbicide cost, $A$ Pretilachlor (pre-emergence herbicide), $B$ pyrazo sulfuron ethyl (post-emergence herbicide), $C_{a}$ application cost, $Y_{o}$ weedfree crop yield, $P$ value per unit of crop, $L$ proportion of yield loss per unit weed density, $H$ herbicide efficacy $(\%)$

Thus, elimination of unnecessary herbicide applications reduces production costs and increases the net economic return [20]. This study clearly described the competition relationships between weeds and rice and successfully predicted rice yields as a function of weed density and estimated ET values. The results of this study could be used for decision-making concerning herbicide application in direct-seeded rice cultivation. Integration of the rectangular hyperbolic model and standard dose-response curve model was developed [8]. The effect of weed species on the interaction of weeds and rice was also investigated [8].

\section{Conclusions}

Weed dry weights increased hyperbolically with increasing weed density. The individual dry weight of weeds was $1.13-3.63 \mathrm{~g} \mathrm{plant}^{-1}$. The intraspecific competition was 0.0375-0.0383. All the growth and yield components were negatively affected by weeds when comparing the reduction rate of yield components with increasing weed density. By fitting the rectangular hyperbola equation, the estimated rice-weed competitivity was $0.01695-0.01255$ and weed-free rice yield was 4.63-4.75 $\mathrm{t} \mathrm{ha}^{-1}$. Based on the parameters, simulated rice yields as a function of weed interferences showed that the rectangular hyperbolic model described the competition between rice and weed species well in both years. The estimated economic threshold of multi-species weeds was 4.72-9.17 plants $\mathrm{m}^{-2}$.

Open Access This article is distributed under the terms of the Creative Commons Attribution License which permits any use, distribution, and reproduction in any medium, provided the original author(s) and the source are credited.

\section{References}

1. Chuhan BS, Johnson DE (2010) The role of seed ecology in improving weed management strategies in tropics. Adv Agron 105:221-262

2. Chuhan BS (2012) Weed ecology and weed management strategy for dry-seeded rice in Asia. Weed Technol 26:1-13

3. Chuhan BS, Abugho SB (2013) Fertilizer placement affects weed growth and grain yield in dry-seeded rice (Oryza sativa L.) system. Am J Plant Sci 4:1260-1264

4. Cousens R (1985) A simple model relating yield loss to weed density. Ann Appl Biol 107:239-252

5. Cousens R (1987) Theory and reality of weed control thresholds. Plant Protect Q 2:13-20 
6. Cowan P, Weaver SE, Swanton CJ (1998) Interference between pigweed (Amaranthus spp.), barnyardgrass (Echinochloa crusgalli), and soybean (Glycine max). Weed Sci 46:533-539

7. Fazlul I, Karim SMR, Haque SMA, Islam MS (2003) Effect of population density of Echinochloa colonum on rice. Pak J Agron 2(3):120-125

8. Kim DS, Brain P, Marshall EJP, Caseley JC (2002) Modelling herbicide dose and weed density effects on crop: weed competition. Weed Res 42:1-13

9. Kropff MJ, Spitters CJT (1991) A simple model of crop loss by weed competition from early observations on relative leaf area of weeds. Weed Res 31:97-105

10. Lindquist JL, Kropff MJ (1996) Application of an ecophysiological model for irrigated rice (Oryza sativa)-Echinochloa competition. Weed Sci 44:52-56

11. Mahajan G, Chauhan BS, Timsina J, Singh PP (2012) KuldeepSingh Crop performance and water- and nitrogen-use efficiencies in dry-seeded rice in response to irrigation and fertilizer amounts in northwest India. Field Crops Res 134:59-70

12. Mamun MAA, Shultanal R, Bhuiyanl MKA, Mridha AJ, Mazid A (2011) Economic weed management options in winter rice. Pak J Weed Sci Res 17(4):323-331

13. Moon BC, Cho SH, Do Kwon O, Lee SG, Lee BW, Kim DS (2010) Modelling rice competition with Echinochloa crusgalli and Eleocharis kuroguwai in transplanted rice cultivation. J Crop Sci Biotech 13(2):121-126
14. Ni H, Moody K, Robles RP, Restituta P (2004) Analysis of competition between wet-seeded rice and barnyardgrass (Echinochloa crus-galli) using a response-surface model. Weed Sci 52:142-146

15. Swinton WM, Buhler DD, Forcella F, Gunsolus JL, King RP (1994) Estimation of crop yield loss due to interference by multiple weed species. Weed Sci 42:103-109

16. Smith RJ (1983) Weeds of major economic importance in rice and yield losses due to weed competition. Proceedings of the Conference on Weed Control in Rice. IRRI, Los Banos, pp 19-36

17. Sultana R (2000) Competitive ability of wet-seeded boro rice against Echinochloa crusgalli and Echinochloa colonum. M.S. Thesis, pp: 36-50. Bangladesh Agricultural University, Mymensingh, Bangladesh

18. Swanton CJ, Murphy SD (1996) Weed science beyond the weeds: the role of integrated weed management (IWM) in agro ecosystem health. Weed Sci 44:437-445

19. Tanaka I (1976) Climatic influence on photosynthesis and respiration of rice plants. Climate and Rice, International Rice Research Institute, Los Banos, Laguna, Philippines

20. Vandevender KW, Costello T, Smith RJ (1997) Model of rice (Oryza sativa L.) yield reduction as a function of weed interference. Weed Sci 42:218-224

21. Wilson BJ, Wright KJ, Brain P, Clements M, Stephens E (1995) Predicting the competitive effects of weed and crop density on weed biomass, weed seed production and crop yield in wheat. Weed Res 35:265-278 